\title{
Universiteit
}

Leiden

The Netherlands

\section{Chemical differentiation of plant latexes and their anti-herbivory activity against thrips Frankliniella occidentalis (\#)}

Salome Abarca, L.F.; Toorn, T.J.C. van der; Vugt, R.R. van; Klinkhamer, P.G.L.; Choi, Y.H.

\section{Citation}

Salome Abarca, L. F., Toorn, T. J. C. van der, Vugt, R. R. van, Klinkhamer, P. G. L., \& Choi, Y. H. (2021). Chemical differentiation of plant latexes and their anti-herbivory activity against thrips Frankliniella occidentalis (\#). Planta Medica, 87(12/13), 1032-1044. doi:10.1055/a-1529-8370

Version: $\quad$ Publisher's Version

License: $\quad$ Licensed under Article 25fa Copyright Act/Law (Amendment Taverne)

Downloaded from: https://hdl.handle.net/1887/3248551

Note: To cite this publication please use the final published version (if applicable). 


\section{Chemical Differentiation of Plant Latexes and Their Anti-herbivory Activity against Thrips Frankliniella occidentalis"}

\author{
Authors \\ Young Hae Choi ${ }^{1,4}$ \\ Affiliations \\ 1 Natural Products Laboratory, Institute of Biology, Leiden \\ University, Leiden, The Netherlands \\ 2 Hortus Botanicus Leiden, Leiden University, Leiden, \\ The Netherlands \\ 3 Plant Ecology and Phytochemistry, Institute of Biology, \\ Leiden University, Leiden, The Netherlands \\ 4 College of Pharmacy, Kyung Hee University, Seoul, \\ Republic of Korea
}

Luis Francisco Salomé-Abarca ${ }^{10}$, Thomas van der Toorn ${ }^{1}$, Rogier van Vugt ${ }^{2}$, Peter G. L. Klinkhamer ${ }^{3}$,

Key words

Apocynaceae, Euphorbiaceae, Moraceae, Clusiaceae, triterpenes, organic acids, latex

$\begin{array}{ll}\text { received } & \text { December } 23,2020 \\ \text { accepted after revision } & \text { June } 10,2021 \\ \text { published online } & \text { July } 8,2021\end{array}$

Bibliography

Planta Med 2021; 87: 1032-1044

DOI $10.1055 / \mathrm{a}-1529-8370$

ISSN 0032-0943

(C) 2021. Thieme. All rights reserved.

Georg Thieme Verlag KG, Rüdigerstraße 14,

70469 Stuttgart, Germany

Correspondence

Dr. Luis Francisco Salomé Abarca

Natural Products Laboratory, Institute of Biology,

Leiden University

Sylviusweg 72, 2333 BE Leiden, The Netherlands

Phone: + 315274510 , Fax: + 315274511

luis.salome@colpos.mx
Supplementary material is available under
https://doi.org/10.1055/a-1529-8370

\begin{abstract}
Despite the extensive studies on latex, some fundamental questions on their chemical specialization and the factors influencing this specialization have yet to be investigated. To address this issue, latexes and their bearing tissues from diverse species were profiled by ${ }^{1} \mathrm{HNMR}$ and GC-MS. Additionally, the antiherbivory activity of these materials was tested against thrips (Frankliniella occidentalis Pergande, 1895). The multivariate data analysis showed a clear separation between latexes and leaves from the same species. Conversely, the chemical profiles of latexes from different species were highly similar, that is, they displayed much less metabolic speciesspecificity. These shared chemical profiles of latexes were reflected in their overall higher mortality index $(80.4 \% \pm 7.5)$ against thrips compared with their bearing tissues (55.5\% \pm 14.9 ). The metabolites correlated to the antiherbivory activity of latexes were triterpenoids and steroids. However, the activity could not be attributed to any single terpenoid. This discrepancy and the reduction of the latex activity after fractionation suggested a complementary effect of the compounds when in a mixture as represented by the latex. Additionally, aqueous fractions of several latexes were found to possess simple spectra, even with only 1 metabolite. These metabolites were determined to be organic acids that might be involved in the modulation of the rate of latex coagulation, potentially increasing the sealing and trapping effects of the latex.
\end{abstract}

\section{Introduction}

Plant latexes are generally milky saps that are stored in specialized cells called laticifers. They are common in some plant groups, occurring in about $8-10 \%$ of all Angiosperms and terrestrial plants [1-4]. They are exuded immediately as a response to mechanical wounding or herbivory at the damaged points [1] and are seemingly a selective adaptation of plant families that have been highly exposed to herbivory $[1,2]$. Some plant families have evolved very chemo-specific latex compositions such as Asclepiadaceae, Sapotaceae, Apocynaceae, and Euphorbiaceae [5].

The physical and chemical characteristics of latexes support their potential role in plant defense mechanisms since they can provide not only mechanical protection but also biochemical defense such as coagulation, toxicity, or antifeeding effects $[1,6]$.

\footnotetext{
\# For inclusion in the special issue of Planta Medica dedicated to Arnold Vlietinck on the occasion of his 80th birthday.
} 
These options are plausible because of the activity of 3 major types of latex components (i.e., proteins, rubber, and a wide range of small molecules). The chemical diversity of latex lies in the latter, and they include terpenes, alkaloids, cardenolides, coumarins, and nonprotein amino acids $[2,7,8]$.

It is generally accepted that the metabolites in latexes are mainly associated with anti-herbivory effects, and there are plenty of studies on the specialized metabolites released upon infection or infestation. For example, it has been determined that their local concentration increases, even within minutes, specifically at points of herbivory damage [9-14]. It has also been proposed that latexes could be a reservoir of species-specific bioactive metabolites such as phytoalexins [15].

Besides the species-specific defense involving small molecules, latexes also constitute a basic or nonspecies-specific line of defense, involving particles of rubber, a typical component that can polymerize entrapping even whole insects [ 1,2$]$. This is supported by the fact that all latexes, regardless of their bearing species, are well known to be able to coagulate, a conserved mechanical defense. Several other latex metabolites that are common to many species could suggest that latexes conserve chemical features associated with basic functions during plant defense. This would imply that the chemical profile of latexes is relatively independent of environmental factors. The profile of induced metabolites of latexes, on the other hand, could be affected by environmental factors, for example, to those responding to plant-specialist herbivore interactions in different geographical regions.

Whereas the studies of the roles of induced specialized metabolites in latexes are increasing [16-18], more general roles, possibly involving constitutive metabolites, still remain unclear, and not much is known beyond their sealing and trapping capabilities mediated by rubber after coagulation. Therefore, a comparison of multi-species chemical profiles of latexes could reveal possible roles of common or constitutive latex metabolites. With this in mind, an approach that could provide information on the overall chemical variation of the latexes from diverse sources was deemed more appropriate than a targeted analysis since it could offer a holistic picture of the metabolic features, which could, in turn, be reflected in a differentiated biological activity of latex in comparison with that of the plants.

Among diverse chemical profiling technologies, NMR spectroscopy and MS-based platforms are the most suitable for this kind of approach, considering their performance in essential aspects such as identification capability, reproducibility, and/or sensitivity [1923]. In this study, both analytical platforms $-{ }^{1} H N M R$ for general metabolome discrimination and GC-MS for target analysis of triterpenes, fatty acids, and steroids-were used in an initial stage to chemically characterize latexes and compare them with their bearing tissues by multivariate data analysis (MVDA). To detect the metabolites common to the distinctive latexes' chemical profiles, 12 different plant species were collected to study their latex and leaves. After chemical profiling, the biological activities of the collected tissues were tested and compared to deduce the role of latex metabolites. For this, a generalist herbivore, the western flower thrips (Frankliniella occidentalis Pergande, 1895) was selected due to its reliability as a model for testing antiherbivory properties of plant metabolites [24, 25].
Thus, metabolomic analysis of diverse latexes and their bearing tissues followed by their biological testing was carried out. The roles of some metabolites in plant defense system were deduced based on the correlation between metabolomics and biological analysis.

\section{Results and Discussion}

Proton nuclear magnetic resonance ( $\left.{ }^{1} \mathrm{HNMR}\right)$ was used as a macroscale metabolic profiling tool to determine and compare the chemical classes specifically accumulated in the latexes. Twelve plant species were collected to obtain their latexes (9 rubbery latexes and 3 clear latexes) and leaves. The visual inspection of the ${ }^{1} \mathrm{HNMR}$ spectra of the $\mathrm{MeOH}$ extracts measured in $\mathrm{CH}_{3} \mathrm{OH}-d_{4}$ indicated that, in general, the level of terpenes was much higher in latexes than in leaves. This was confirmed by comparing characteristic terpenoidal methyl resonances in the $\delta 0.7-\delta 1.8$ range. In addition to these methyl signals, some latexes showed 2 more distinct resonances at $\delta 0.35(\mathrm{~d}, J=4.1 \mathrm{~Hz})$ and $\delta 0.55(\mathrm{~d}$, $J=4.1 \mathrm{~Hz}$ ), which were assigned to the $\mathrm{H}$-19endo and $\mathrm{H}$-19exo in the cyclopropane ring of 24-methylenecycloartanol. Thus, based on the visual inspection of the ${ }^{1} \mathrm{HNMR}$ spectra, latex metabolomes were clearly distinguished by their high concentration of triterpenes while fatty acids, phenolics, and sugars were found to be more accumulated in leaves, showing a large variation in their content among the tested species.

The ${ }^{1} \mathrm{HNMR}$ dataset was submitted to MVDA. The principal component analysis (PCA) of all methanol extracts showed 2 main clusters along the PC1 (tissue) ( $\triangleright$ Fig. 1 a). Interestingly, most of the latexes were well clustered despite belonging to completely different species. This was more evident for rubbery latexes (Alstonia scholaris [L.] R. Br., Acokanthera oblonguifolia [Hochst.] Benth. \& Hook.f. ex B.D.Jacks, Allamanda spp., Dischidia bengalensis Colebr., Plumeria rubra L., Euphorbia myrsinites L., Euphorbia tirucalli L., Clusia rosea Jacq., and Ficus natalensis subsp. leprieurii [Miq.] C.C.Berg) that clustered together. This means the metabolic variation of latexes was much lower than that of leaves. This tight clustering of rubbery latexes could result from the presence of conserved constitutive metabolites of latexes such as triterpenoids. These metabolites were observed in the visual inspection of the ${ }^{1}$ HNMR analysis and confirmed by the PCA loading plot. The further analysis of the data set by orthogonal projection to latent structures-discriminant analysis (OPLS-DA) corroborated $\left(Q^{2}=0.86, p<0.01\right)$ that the discrimination between latexes and leaves was due to terpenoid-like compounds ( $\bullet$ Fig. $\mathbf{1 b}$ ). For a deeper insight into the structures of terpenoidal and other metabolic groups of both leaves and latexes, the samples were successively extracted with dichloromethane, ethyl acetate, and water. Each fraction was measured by ${ }^{1} \mathrm{HNMR}$, and the resulting data were analyzed by OPLS-DA using latex and leaves as classes. Considering the lipophilicity of terpenoids, the dichloromethane fraction was first analyzed. Its model was highly validated with a $Q^{2}=0.85$ in the permutation test, and $p<0.01$ in the CV-ANOVA test ( $\vee$ Fig. $1 \mathbf{c}$ ).

In the case of leaf samples, the S-plot of the OPLS-DA model showed a range of chemical shifts corresponding to fatty acids such as palmitic, stearic, linoleic, and oleic acids, the identity of 

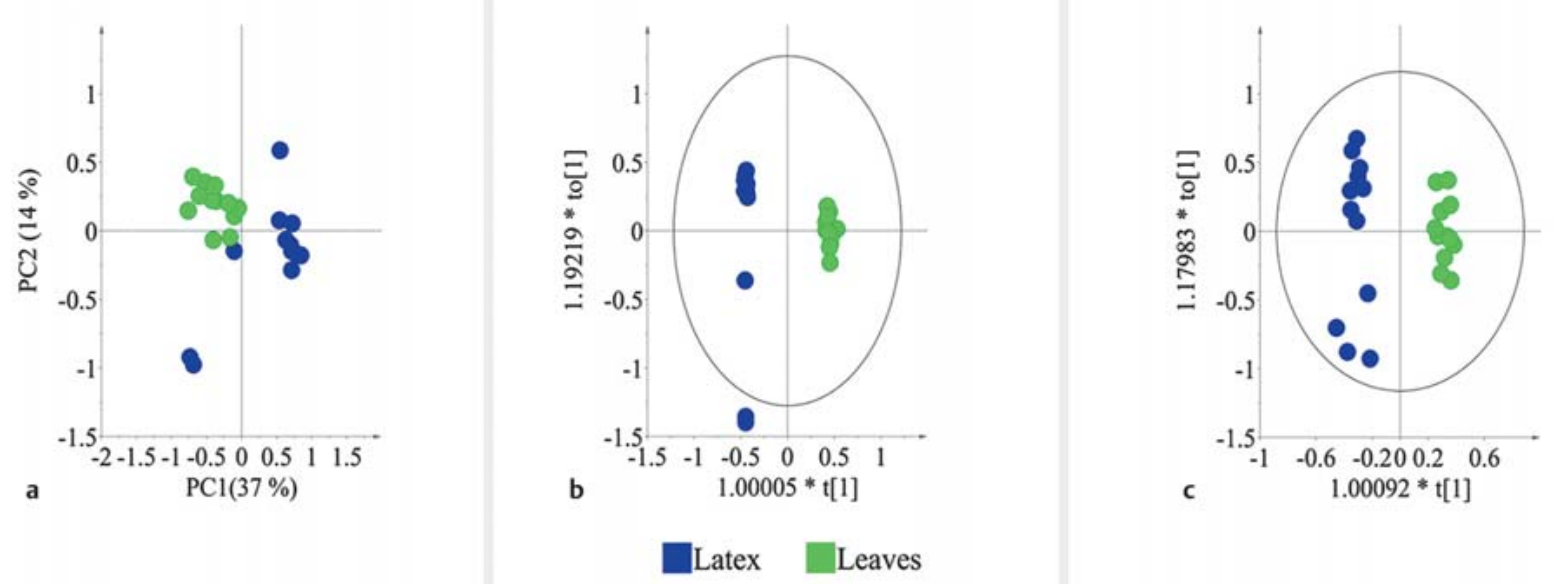

Fig. 1 Multivariate data analysis of the methanol extracts and dichloromethane fractions of latexes and leaves of 12 plant species. a Principal component analysis (PCA) of the methanol extracts of latexes and leaves. b Orthogonal partial least square discriminant analysis (OPLS-DA) of the methanol extracts of latexes and leaves. c OPLS-DA model of the dichloromethane fractions of latexes and leaves.

which was confirmed by GC-MS analysis. The higher concentration of fatty acids in leaves might be associated with a specific defense mechanism of this tissue and membrane composition. In this sense, these acids could function not only as membrane components but also as defensive molecules in response to plant damage. Fatty acids can be converted into fatty acid hydroperoxides, and these can further degrade to highly reactive epoxides, aldehydes, $\gamma$-ketols, or even reactive oxygen species $[26,27]$. These compounds cause protein agglutination and chemical modifications of essential amino acids, which result in their deficient assimilation by herbivores [26]. Additionally, the end products of peroxidized lipids produce antixenosis or antibiosis effects against herbivores $[28,29]$. These characteristics could favor the location and accumulation of fatty acids in leaves as the outer layer of plant defense.

On the other hand, the loadings values associated with latexes were 2 singlets in the range of $\delta 1.8-\delta 2.0$ that were assigned to acetyl protons from lupeol acetate, cycloartenol acetate, and $\beta$ amyrin acetate. Moreover, other methyl signals of terpenes in the $\delta 0.8-\delta 1.0$ range were also associated with latexes. The identity of these compounds was determined by GC-MS analysis. Differently from leaves, latexes could play a role in plant defense systems as one of the first protective barriers against pathogens and herbivores but based on a generalist mechanism. Latexes could be exuded producing a broad and general physical and chemical retardation of the attack by natural enemies, giving the plant time to set up the more sophisticated defense system based on induced metabolites.

This hypothesis was in line with the proposal of triterpenoids as a conserved metabolic class in latexes throughout diverse species. It is important to note, though, that while some triterpenoids were common to most latexes, some were species-specific. Characteristic signals in the range of $\delta 0.6-\delta 1.6$ in the dichloromethane fractions of the latex of $A$. oblonguifolia were assigned to methyl protons of cycloartenol and $\beta$-amyrin and 2 triplets at $\delta 5.04$ and $\delta 5.28$ were assigned to the $\mathrm{H}-24$ and $\mathrm{H}-12$ of cyclo- artenol and $\beta$-amyrin respectively. Two typical double doublets at $\delta 3.06(\mathrm{dd}, J=11.4,4.4 \mathrm{~Hz}$ ) and $\delta 3.15(\mathrm{dd}, J=11.4,4.4 \mathrm{~Hz}$ ) were assigned to the $\mathrm{H}-3$ also from these triterpenoids. In the dichloromethane fraction of $A$. scholaris and $D$. bengalensis, diagnostic signals for protons from the side chain at the $C 19$ of lupeol acetate were detected as 2 broad singlets at $\delta 4.66$ and $\delta 4.59$ corresponding to $\mathrm{H}-29 \mathrm{a}$ and $\mathrm{H}-29 \mathrm{~b}$, respectively and a singlet at $\delta 1.62$ assigned to $\mathrm{H}-30$ on the same side chain, a signal at $\delta 3.15$ (dd, $J=11.4,4.4 \mathrm{~Hz}$ ) corresponding to $\mathrm{H}-3$ next to an ester bond with an acetyl group, observed as a singlet between $\delta 1.95-\delta 1.97$ confirmed the identification.

The ${ }^{1}$ HNMR spectrum of $A$. scholaris latex also showed typical signals for cyclopropyl-containing triterpenoids or steroids in the range of $\delta 0.1-\delta 0.6$. One of the compounds was detected at $\delta 0.57(\mathrm{H}-19 \mathrm{a}, \mathrm{d}, J=4.1 \mathrm{~Hz})$ and $\delta 0.41(\mathrm{H}-19 \mathrm{~b}, \mathrm{~d}, J=4.1 \mathrm{~Hz})$, and the other was at $\delta 0.35(\mathrm{H}-19 \mathrm{a}, \mathrm{d}, J=4.1 \mathrm{~Hz})$ and $\delta 0.17(\mathrm{H}-19 \mathrm{~b}$, $\mathrm{d}, J=4.1 \mathrm{~Hz}$ ). Several acetyl protons (s) were detected in the range of $\delta 1.95-\delta 1.97$. In addition, an olefinic proton at $\delta 5.13(\mathrm{H}-12, \mathrm{t}$, $J=3.5 \mathrm{~Hz}$ ) was assigned to the $\mathrm{C}$ ring of $\beta$-amyrin acetate ( $\bullet$ Fig. 2).

The latexes of $C$. rosea, E. myrsinites, and E. tirucalli showed characteristic methyl proton signals for a lanostan skeleton. Singlets at $\delta 0.73(\mathrm{H}-28$ and $\mathrm{H}-29), \delta 0.84(\mathrm{H}-30), \delta 0.91(\mathrm{H}-18)$, $\delta 0.92(\mathrm{H}-19)$, and $\delta 1.54(\mathrm{H}-27)$ and a small doublet with geminal coupling $(\mathrm{d}, J=0.8 \mathrm{~Hz})$ at $\delta 1.61$ were assigned to $\mathrm{H}-26$. The last 2 resonances are a typical pattern for a terminal isopropylidene group on the side chain of euphol-like compounds. Further, a doublet at $\delta 0.81(\mathrm{H}-21, \mathrm{~d}, J=6.3 \mathrm{~Hz})$ was assigned to a secondary methyl group in C21 of the same side chain ( $\bullet$ Fig. 2 ). The identification of triterpenoids by ${ }^{1} \mathrm{HNMR}$ data was supported by additional GC-MS analysis. All the metabolites detected in latexes by ${ }^{1}$ HNMR and GC-MS are listed in > Table 1.

After the analysis of lipophilic metabolites in the dichloromethane fraction, the aqueous fractions were analyzed by ${ }^{1}$ HNMR. In general, the water fractions of latexes were found to be rich in primary metabolites such as sugars and organic acid de- 
- Table 1 Compounds detected by ${ }^{1}$ H NMR and GC-MS in the dichloromethane fraction of latexes from 12 plant species.

\begin{tabular}{|c|c|c|c|c|c|c|c|c|c|c|c|c|}
\hline Compounds & AS & AO & Al & DB & PR & ADO & CR & FT & ET & EM & $\mathrm{JC}$ & JM \\
\hline $\begin{array}{l}\text { dasycarpidan-1-methanol, } \\
\text { acetate (ester) }\end{array}$ & - & - & - & - & GC & - & - & - & - & - & - & - \\
\hline$\alpha$-linoleic acid & - & - & - & - & - & - & - & - & - & - & - & GC \\
\hline (cis)-6-octadecenoic acid & - & - & - & - & - & - & - & - & GC & - & - & GC \\
\hline cis-13-eicosenoic acid & - & - & - & - & GC & - & - & - & - & - & - & - \\
\hline oleic acid & - & - & GC & - & - & - & - & - & - & - & - & - \\
\hline octadecanoid acid & GC & - & GC & - & - & GC & - & - & GC & - & GC & - \\
\hline hexanedioic acid & GC & - & GC & GC & - & GC & - & - & GC & - & GC & GC \\
\hline squalene & - & - & - & - & - & - & - & ${ }^{1} \mathrm{H} / \mathrm{GC}$ & - & - & - & - \\
\hline$\beta$-amyrin* & ${ }^{1} \mathrm{H} / \mathrm{GC}$ & ${ }^{1} \mathrm{H} / \mathrm{GC}$ & - & - & - & - & - & - & GC & - & - & - \\
\hline$\alpha$-amyrin ${ }^{*}$ & GC & GC & - & - & - & - & - & - & - & - & - & - \\
\hline cycloeucalenyl acetate & ${ }^{1} \mathrm{H} / \mathrm{GC}$ & - & - & ${ }^{1} \mathrm{H} / \mathrm{GC}$ & - & - & - & - & - & - & - & - \\
\hline cycloartenol & ${ }^{1} \mathrm{H} / \mathrm{GC}$ & ${ }^{1} \mathrm{H} / \mathrm{GC}$ & - & & - & - & - & - & - & - & - & - \\
\hline lanosterol/euphol & - & ${ }^{1} \mathrm{H} / \mathrm{GC}$ & - & ${ }^{1} \mathrm{H} / \mathrm{GC}$ & - & - & ${ }^{1} \mathrm{H} / \mathrm{GC}$ & ${ }^{1} \mathrm{H} / \mathrm{GC}$ & ${ }^{1} \mathrm{H} / \mathrm{GC}$ & ${ }^{1} \mathrm{H} / \mathrm{GC}$ & - & - \\
\hline $\begin{array}{l}\text { 9,19-cyclo-(9 } \beta) \text {-lanost-24-en- } \\
3 \beta \text {-ol }\end{array}$ & - & - & - & & - & - & - & - & - & GC & - & - \\
\hline $\begin{array}{l}\text { (3ß)-24-methylene- } \\
\text { cycloartan-3-ol }\end{array}$ & - & - & - & & - & - & - & - & - & - & - & - \\
\hline lanosterone & - & - & - & & - & - & - & GC & - & - & - & - \\
\hline lupeol acetate & ${ }^{1} \mathrm{H} / \mathrm{GC}$ & ${ }^{1} \mathrm{H} / \mathrm{GC}$ & - & ${ }^{1} \mathrm{H} / \mathrm{GC}$ & ${ }^{1} \mathrm{H} / \mathrm{GC}$ & - & - & - & - & - & - & - \\
\hline lupenone* & - & - & - & & & - & - & GC & - & - & - & - \\
\hline $\begin{array}{l}\text { 3-acetoxy-7,8-Epoxylanostan- } \\
\text { 11-ol }\end{array}$ & - & - & - & & GC & - & - & - & - & - & - & - \\
\hline$\beta$-amyrin acetate & ${ }^{1} \mathrm{H} / \mathrm{GC}$ & - & - & ${ }^{1} \mathrm{H} / \mathrm{GC}$ & - & - & - & - & - & - & - & - \\
\hline 24-methylenecycloartanol* & ${ }^{1} \mathrm{H} / \mathrm{GC}$ & ${ }^{1} \mathrm{H} / \mathrm{GC}$ & - & ${ }^{1} \mathrm{H} / \mathrm{GC}$ & - & - & - & - & - & - & - & - \\
\hline stigmasterol* & - & - & - & GC & - & - & - & GC & - & - & - & - \\
\hline$\beta$-sitosterol ${ }^{*}$ & - & - & GC & - & - & - & - & - & - & - & - & - \\
\hline 24-methylenelophenol & - & - & GC & GC & - & - & - & - & - & - & - & - \\
\hline Friedelin & - & - & - & GC & - & - & - & - & - & - & - & - \\
\hline betulin* & - & - & - & - & - & - & - & GC & GC & - & - & - \\
\hline $\begin{array}{l}\text { (3ß)-3-(acetyloxy)-urs-12-en- } \\
28 \text {-al }\end{array}$ & - & - & - & - & GC & - & - & - & - & - & - & - \\
\hline cycloartenol acetate & - & - & - & - & - & - & - & GC & - & - & - & - \\
\hline
\end{tabular}

rivatives. Similar to the dichloromethane fractions, the OPLS-DA showed a separation of leaves and latexes in 2 clusters. However, the model was not validated either by the $Q^{2}$ value $\left(Q^{2}<0.40\right)$ of the permutation test or the p-value from the CV-ANOVA $(p>0.01)$. This nonseparation could be attributed to the presence of species-specific latex-discriminating metabolites in these fractions. That is, these metabolites could be slightly different ana- logs, causing some inconsistency within the cluster that caused the discrimination between the leaves and the latex in the model to be less clear cut. However, interestingly, the spectra of some of the latex water fractions (i.e., A. scholaris, $E$. myrsinites, and $P$. rubra) were actually very simple, showing the presence of a few major organic acids as shown in $>$ Fig. 3 . 


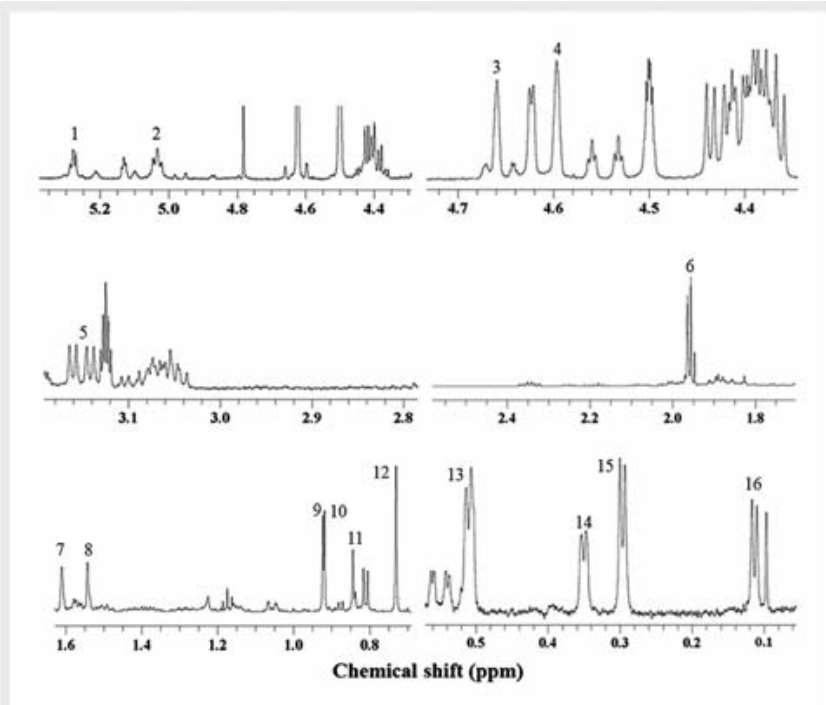

- Fig. 2 Diagnostic signals of specific terpenoids in latexes' dichloromethane fractions measured in $\mathrm{CH}_{3} \mathrm{OH}-d_{4}$. 1: $\mathrm{H}-12$ of $\beta$-amyrin, 2: $\mathrm{H}-24$ of cycloartenol, 3: $\mathrm{H}-29 \mathrm{a}$ of lupeol acetate, 4: $\mathrm{H}-29 \mathrm{~b}$ of lupeol acetate, 5: $\mathrm{H}-3$ of $\beta$-amyrin, 6: acetyl protons of lupeol acetate, and $\beta$-amyrin acetate, 7: $\mathrm{H}-26,8: \mathrm{H}-27,9: \mathrm{H}-19,10: \mathrm{H}-18,11: \mathrm{H}-30,12$ : $\mathrm{H}-28$, and $\mathrm{H}-29$ of a lanostan skeleton, 13-16: $\mathrm{H}-19$ (cyclopropanol moiety) of cycloartanols like compounds.

In the ${ }^{1} \mathrm{HNMR}$ spectrum of aqueous extracts of $E$. myrsinites, 3 distinguished $\mathrm{H}-3$ of shikimic acid moiety (1-3) were detected in the range of $\delta 6.5-\delta 6.7$ and correlated with $\mathrm{H}-3$ at $\delta 4.43, \delta 4.55$, and $\delta 5.54$, respectively. The correlations between the signals in shikimic acid moiety was confirmed by ${ }^{1} \mathrm{H}-{ }^{1} \mathrm{H}-\mathrm{COSY}$ spectrum (Fig. 1S, Supporting Information). Three sets of meglutol (3-hydroxy-3-methylglutaric acid) moiety were confirmed by the characteristic doublets of $\mathrm{H}-2^{\prime}$ at $\delta 2.73, \delta 2.71$, and $\delta 2.68$, together with $\mathrm{H}-4^{\prime} \mathrm{a}$ and $\mathrm{H}-4^{\prime} \mathrm{b}$ in $\delta 2.52-\delta 2.58(\mathrm{~d}, J=15.3 \mathrm{~Hz}$ ). The conjugation positions of 3 isomers between shikimic acid and meglutol moieties were confirmed by $\mathrm{HMBC}$ correlation between $\mathrm{H}-3, \mathrm{H}-4$, and $\mathrm{H}-5$ and carbonyl group (C-1' at 171.8) (Fig. 2S, Supporting Information). The important HMBC correlations of compound 1 were shown in $>$ Fig. 4.

2-Methoxysuccinic acid (4) was confirmed in the aqueous extracts of $A$. scholaris latex by the presence of $\mathrm{H}-2$ at $\delta 3.99$ (dd, $10.5,3.0 \mathrm{~Hz}$ ), $\mathrm{H}-3 \mathrm{a}$ at $\delta 2.60$ (dd, $J=15.4,3.0 \mathrm{~Hz}$ ) and $\mathrm{H}-3 \mathrm{~b}$ at $\delta 2.39(\mathrm{dd}, J=15.4,10.5 \mathrm{~Hz})$. The methoxy signals at $\delta 3.32(\mathrm{~s})$ were correlated to C-2 at $\delta 80.3$ in HMBC spectrum (Fig. 3S, Supporting Information).

The latex of $P$. rubra was found to have a higher concentration of cerberic acid B (5), a dihydrophenylpropanoid in their aqueous fraction. Four aromatic signals at $\delta 7.82(\mathrm{t}, J=1.8 \mathrm{~Hz}), \delta 7.44(\mathrm{dt}$, $J=7.6,1.5 \mathrm{~Hz}), \delta 7.38(\mathrm{t}, J=7.6 \mathrm{~Hz})$, and $\delta 7.77(\mathrm{dt}, J=7.6$, $1.5 \mathrm{~Hz}$ ) were assigned to $\mathrm{H}-2, \mathrm{H}-4, \mathrm{H}-5$, and $\mathrm{H}-6$. The ${ }^{1} \mathrm{H}$ resonances of propyl moiety of the compound were detected at $\delta 4.21(\mathrm{H}-7, \mathrm{dd}, J=8.3,3.9 \mathrm{~Hz}), \delta 3.15(\mathrm{H}-8 \mathrm{a}, \mathrm{dd}, J=14.0,3.9 \mathrm{~Hz})$, and $\delta 2.88(\mathrm{H}-8 \mathrm{a}$, dd, $J=14.0,8.3 \mathrm{~Hz})$. The ${ }^{1} \mathrm{H}-{ }^{1} \mathrm{H}-\mathrm{COSY}$ correlations were shown in Fig. $4 \mathrm{~S}$ (Supporting Information).
The detailed assignments of all the ${ }^{1} \mathrm{H}$ resonances of the compounds are shown in $\mathbf{T}$ Table 2 . Thus, the major hydrophilic latex metabolites were found to be 3 isomers of meglutoloyl shikimic acid in E. myrsinites, compound 4 in A. scholaris, and compound 5 in $P$. rubra. The concentration of all the acids accounted for above $90 \%$ of the dry weight of the water fractions of latexes. Among the detected compounds, compound 4 has been reported for the first time in nature. The detailed assignments of the ${ }^{1} \mathrm{H}$ resonances of these acids are listed in $\boldsymbol{\nabla}$ Table $\mathbf{2}$ together with their chemical structures ( $\bullet$ Fig. $\mathbf{5}$ ). Other metabolites found in latex water fractions were chlorogenic acid, quinic acid, sucrose, and formic acid. The ethyl acetate fractions resulted in a mixture of compounds found in the dichloromethane and water fractions. Their OPLS-DA model resulted in no separation in the score plot with invalidated $\mathrm{Q}^{2}$ and $\mathrm{p}$-value, similarly to what occurred with water fractions. These results reinforce the proposal of terpenelike triterpenoids and sterols as distinctive metabolites of latexes. At the same time, the extremely high concentration of specific metabolites in latexes, terpenoids, and organic acids, suggested a possible biological role very likely related to plant defense. To prove this hypothesis, the methanol extracts of latexes and leaves were tested against Frankliniella occidentalis (thrips).

Latex-based diets generally displayed a significantly higher mortality index of thrips compared to those of leaf-based diets $(p<0.0001)$ ( $\triangleright$ Fig. 6 a). The average mortality rate observed with all the latex extracts was $80.42 \% \pm 1.74$ while that of leaves was $55.53 \% \pm 3.56$, with no significant variation of the mortality among latex of different species. This result indicates that the conserved chemical features of latexes are well distinguished from their bearing tissues and could be related to biological functions such as antiherbivory. In fact, a partial least square (PLS) model of the activity and the intensity of ${ }^{1} \mathrm{HNMR}$ resonances of the $\mathrm{MeOH}$ extracts was well-validated $\left(Q^{2}=0.41, \mathrm{p}<0.05\right)$ ( $\bullet$ Fig. 7). The PLS loading values associated with the antiherbivore activity were signals in the $\delta 0.3-\delta 1.7$ range corresponding to methyl signals of triterpenoids.

Considering the correlation between the mortality index and latex metabolites, some latexes were selected for further study for a deeper insight into their composition. For this, the 6 species with the highest difference in mortality index between latex and their bearing tissues were selected. Thus, the latex of 3 species from the Euphorbiacae (Jatropha multifida L., Jatropha curcas L., and E. myrsinites) and 3 from the Apocynacae (A. scholariş Adenium obesdum [Forssk.] Roem. \& Schult, and $P$. rubra) families were fractionated with dichloromethane, ethyl acetate, and water, and tested against the same herbivore. All 3 fractions showed some degree of activity; but in all cases, their mortality index was around $50 \%$ lower than that of methanol extracts. However, among the 3 fractions, all dichloromethane fractions displayed the highest activity against thrips $(p<0.001)$. This result was consistent with the result of the PLS analysis of methanol extracts that showed a clear correlation of triterpenes to the antiherbivore activity. Thus, due to their lipophilic character, triterpenes were more concentrated in the dichloromethane fractions, justifying their higher activity ( $\bullet$ Fig. $\mathbf{6 b}$ b). The decrease in activity after fractionation strongly suggests a complementary effect between the metabolites from all the fractions although the terpene mixture in 


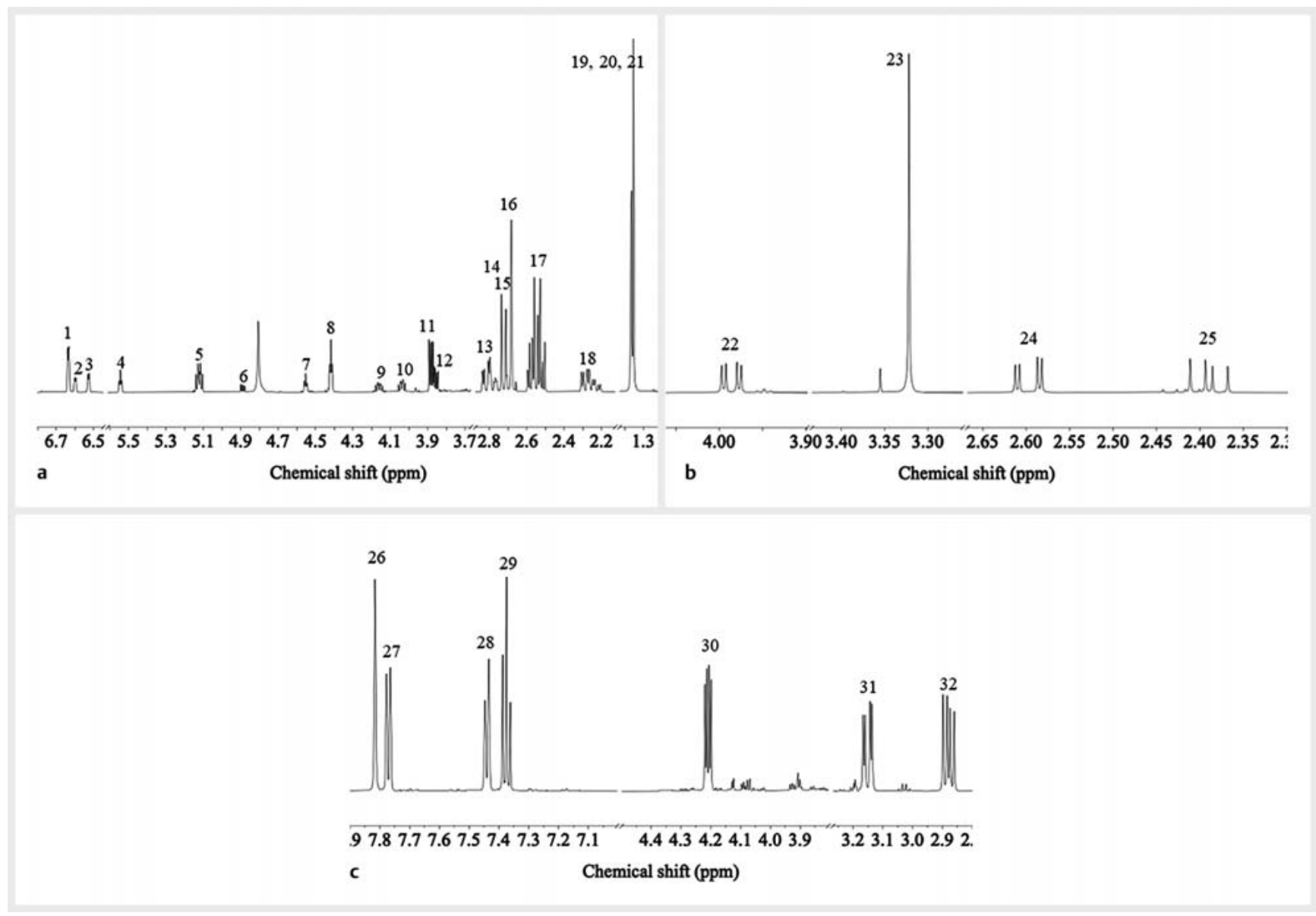

- Fig. $3{ }^{1} \mathrm{HNMR}$ spectra of water fractions from the latexes of Euphorbia myrsinites (a), Alstonia scholaris (b), and Plumeria rubra (c). 1: H-2 of compound 1, 2: $\mathrm{H}-2$ of compound 2, 3: $\mathrm{H}-2$ of compound 3, 4: $\mathrm{H}-3$ of compound 3, 5: H-5 of compound 1, 6: H-4 of compound 2, 7: $\mathrm{H}-3$ of compound 2, 8: H-3 of compound 1, 9: H-5 of compound 2, 10: H-5 of compound 3, 11: H-4 of compound 1, 12: H-4 of compound 3, 13: H-6a of compound 1, 2, 3, 14: $\mathrm{H}-2^{\prime}$ of compound 3, 15: $\mathrm{H}-2^{\prime}$ of compound 2, 16: $\mathrm{H}-2^{\prime}$ of compound 1, 17: $\mathrm{H}-4^{\prime}$ of compound 1, 2, 3 18: $\mathrm{H}-6 \mathrm{~b}$ of compound 1, 2, 3, 19: $\mathrm{CH}_{3}$ of compound 2, 20: $\mathrm{CH}_{3}$ of compound 3, 21: $\mathrm{CH}_{3}$ of compound 1, 22: $\mathrm{H}-2$ of compound 4, 23: $\mathrm{OCH}_{3}$ of compound 4, 24: $\mathrm{H}-3 \mathrm{a}$ of compound 4, 25: $\mathrm{H}-3 \mathrm{~b}$ of compound 4, 26: $\mathrm{H}-2$ of compound 5, 27, H-6 of compound 5, 28: $\mathrm{H}-4$ of compound 5, 29: $\mathrm{H}-5$ of compound 5, 30: $\mathrm{H}-7$ of compound 5, 31: $\mathrm{H}-8 \mathrm{a}$ of compound 5, 32: $\mathrm{H}-8 \mathrm{~b}$ of compound 5 . The detailed information on chemical shifts and coupling constants is listed in $>$ Table 2.

latexes contributes most to their activity. However, there could be another explanation. Some other minor compounds would provide or complement the main antiherbivore effects such as phenolics and alkaloids $[14,30]$. These metabolites possess biological effects, such as nervous system and membrane transport disruption, protein synthesis inhibition, and also affect miscellaneous enzyme activities [31]. Moreover, some of these metabolites can also be potentiated after oxidation [32]. On top of that, it is plausible that active metabolites might be degraded or lost during purification or isolations.

Given the observed activity of the triterpenoid rich fractions, several typical triterpenoids such as betulin, betulinic acid, lupeol, ursolic acid, $\alpha$-amyrin and $\beta$-amyrin, and 24-methylenecycloartanol were tested for antiherbivory at a concentration of $37.5 \mu \mathrm{g} \cdot \mathrm{mL}^{-1}$, corresponding to the levels determined by the quantitation results of ${ }^{1} \mathrm{HNMR}$ of the dichloromethane fractions. All tested individual triterpenoids showed some degree of activity but in no case was close to that of the dichloromethane fractions

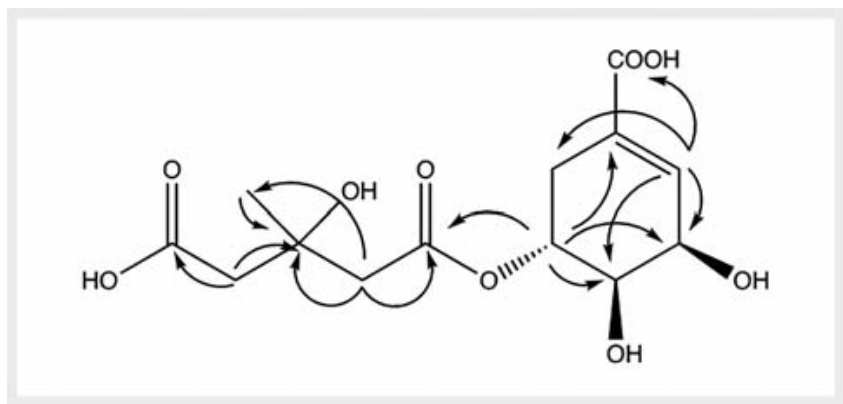

D Fig. 4 Important HMBC correlations in 5-meglutoloyl shikimic acid (5). 
- Table $2{ }^{1} \mathrm{H}$ chemical shifts (in ppm) and coupling constants (in Hz) of 5-meglutoloyl shikimic acid (1), 4-meglutoloyl shikimic acid (2), 3- meglutoloyl shikimic acid (3), 2-methoxysuccinic acid (4), and cerberic acid B (5).

\begin{tabular}{|c|c|c|c|c|c|}
\hline $\begin{array}{l}\text { H posi- } \\
\text { tion }\end{array}$ & Compound $1^{\mathrm{a}}$ & Compound $2^{\mathrm{a}}$ & Compound $3^{a}$ & Compound $4^{b}$ & Compound $5^{a}$ \\
\hline 1 & - & - & - & - & - \\
\hline 2 & $6.63(\mathrm{dt}, 3.9,1.8)$ & $6.60(\mathrm{dt}, 3.9,1.8)$ & $6.53(\mathrm{dt}, 3.9,1.8)$ & $3.99(\mathrm{dd}, 10.5,3.0)$ & $7.82(t, 1.8)$ \\
\hline 3 & 4.43 (brt, 4.2) & 4.55 (brt, 4.2) & 5.54 (brt, 4.2) & $\begin{array}{l}2.60 \text { (H-3a, dd, 15.4, 3.0), } \\
2.39 \text { (H-3b, dd, 15.4, 10.5) }\end{array}$ & - \\
\hline 4 & $3.88(\mathrm{dd}, 8.5,4.2)$ & $4.89(\mathrm{dd}, 8.8,4.2)$ & $3.86(d d, 8.5,4.2)$ & - & $7.44(\mathrm{dt}, 7.6,1.5)$ \\
\hline 5 & $5.12(\mathrm{ddd}, 8.5,6.6,5.4)$ & 4.16 (ddd, $8.8,7.1,5.4)$ & 4.03 (ddd, 8.5, 6.9, 5.3) & - & $7.38(t, 7.6)$ \\
\hline 6 & $\begin{array}{l}2.81 \text { (H-6a, m), } \\
2.29(\mathrm{H}-6 \mathrm{~b}, \mathrm{~m})\end{array}$ & $\begin{array}{l}2.78 \text { (H-6a, m), } \\
2.25 \text { (H-6b, m) }\end{array}$ & $\begin{array}{l}2.78 \text { (H-6a, m), } \\
2.23 \text { (H-6b, m) }\end{array}$ & - & $7.77(\mathrm{dt}, 7.6,1.5)$ \\
\hline 7 & - & - & - & - & $4.21(\mathrm{dd}, 8.3,3.9)$ \\
\hline 8 & - & - & - & - & $\begin{array}{l}3.15 \text { (H-8a, dd, 14.0, 3.9), } \\
2.88 \text { (H-8b, dd, 14.0, 8.3) }\end{array}$ \\
\hline $2^{\prime}$ & 2.68 (brs) & 2.71 (brs) & 2.73 (brs) & - & - \\
\hline $4^{\prime}$ & $\begin{array}{l}2.57 \text { (H-3'a, d, 15.3), } \\
2.52 \text { (H-3'b, d, 15.3) }\end{array}$ & $\begin{array}{l}2.58 \text { (H-3'a, d, 15.3), } \\
2.53 \text { (H-3'b, d, 15.3) }\end{array}$ & $\begin{array}{l}2.58 \text { (H-3'a, d, 15.3), } \\
2.53 \text { (H-3'b, d, 15.3) }\end{array}$ & - & - \\
\hline $3^{\prime}-\mathrm{CH}_{3}$ & $1.35(\mathrm{~s})$ & $1.37(\mathrm{~s})$ & $1.36(\mathrm{~s})$ & - & - \\
\hline $2-\mathrm{OCH}_{3}$ & - & - & - & $3.32(s)$ & - \\
\hline
\end{tabular}

and much less that of the methanol extracts ( $\vee$ Fig. $6 \mathrm{c})$. This once more supported the idea of possible complementary effects among components of latex, an idea that is reasonable considering that when a plant defense mechanism includes co-acting features, a positive covariation between specific subgroups of defensive traits would result in more efficient defense strategies [33]. This type of metabolic interaction has been observed in many plant species [33-35].

In addition to the insecticidal properties of latexes' triterpenoids, other potential functions could be inferred from multifunctional characteristics that have been previously reported. Apart from direct insecticidal activity, latex could also be a powerful deterrent. Some terpenoids and steroids confer a bitter taste to plant tissues, making them unpalatable for insect herbivores [36]. Furthermore, terpenoids could also cause growth retardation or even act as chemo-sterilizers of insects, affecting their reproduction and resulting in reduced production of new offspring. Naturally, none of these effects would be reflected in their mortality index. This has been proven for $\beta$-amyrin derivatives [37] and could also partially explain why some pure metabolites did not show direct insecticidal effects. However, this type of supplementary and noninsecticidal mechanism could help avoid or delay herbivores' resistance to plant defense systems. A similar result has been reported for other exudates such as oleoresins. In these exudates, though their single components possessed activity per se, their effect when mixed was found to be potentiated [38]. Triterpenoids are also known to improve membrane permeability. Many sterols are reported to regulate the channels of cell membranes

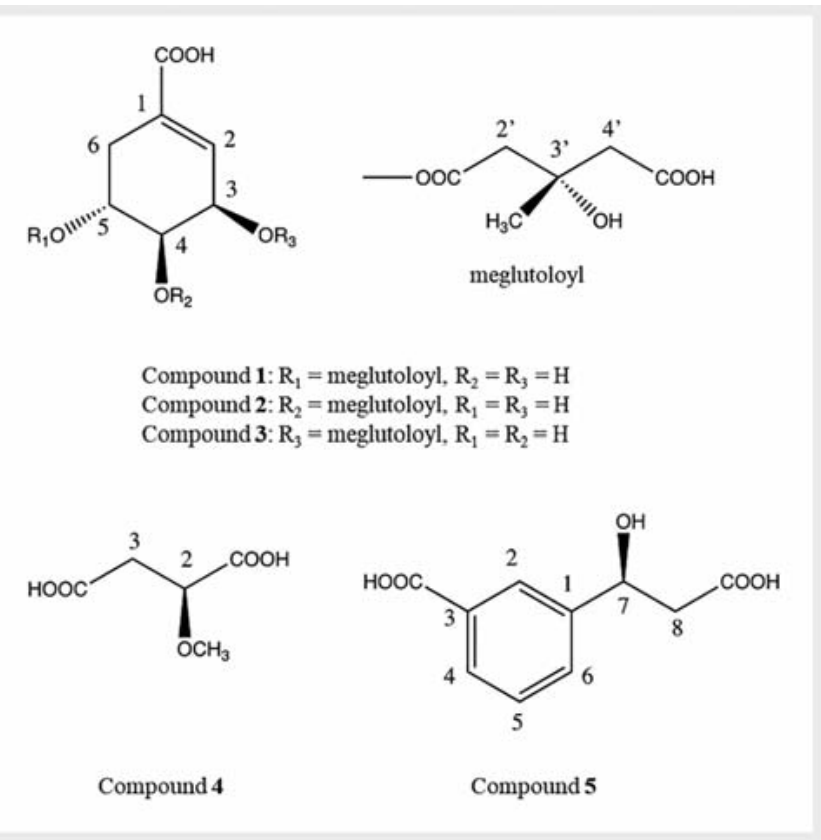

- Fig. 5 Chemical structure of organic acids found in the water fractions of plant latexes. a 5-meglutoloyl shikimic acid (compound 1), 4- meglutoloyl shikimic acid (compound 2), and 3- meglutoloyl shikimic acid (compound 3) found in Euphorbia myrsinites water fraction. b 2-methoxysuccinic acid (compound 4) found in Alstonia scholaris water fraction. c Cerberic acid B (compound 5) found in Plumeria rubra water fraction. 

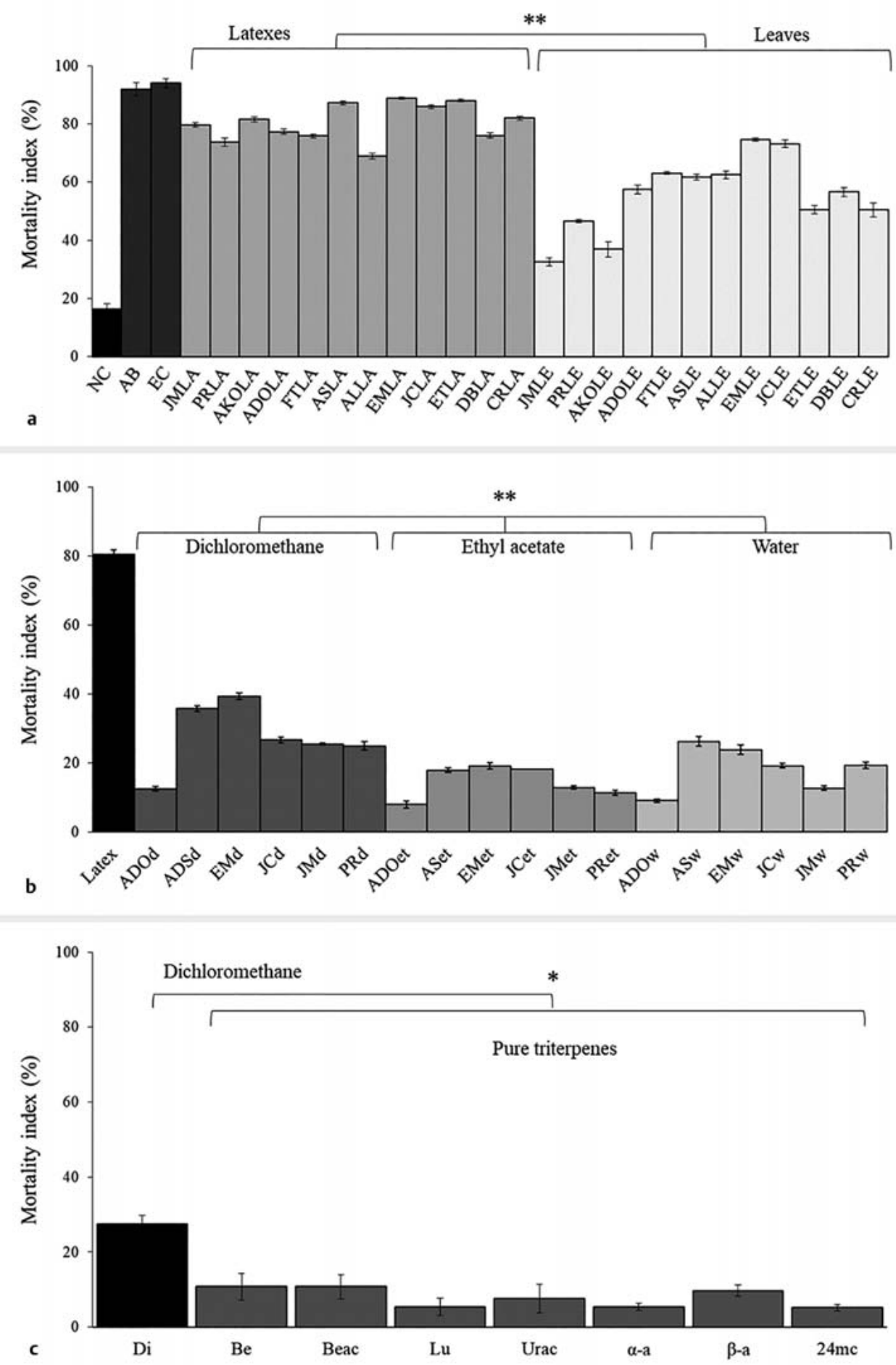

- Fig. 6 Antiherbivore activity of methanol extracts and dichloromethane, ethyl acetate, and aqueous fractions of latexes and leaves of latex-bearing species and some individual triterpenoids. a Methanol extracts of 12 plant species. NC, negative control, AB, abamectine, EC, empty wells, JMLA, Jathropha multifida, PRLA, Plumeria rubra, AKOLA, Akokanthera oblonguifolia, ADO, Adenium obesum, FT, Ficus natalensis, AS, Alstonia scholaris, AL, Allamanda spp., EM, Euphorbia myrsinites, JC, Jathropha curcas, ET, Euphorbia tirucalli, DB, Dischidia bengalensis, CR, Clusia rosea. Species code + suffix "LA" correspond to latex samples and "LE" to leaves extracts. b Dichloromethane, ethyl acetate, and water fractions of latexes from 6 plant species. Species code + suffix "d": dichloromethane fractions; + suffix "et": ethyl acetate fraction; + suffix "w": water fraction. c Individual triterpenoids. Di: dichloromethane fraction; Be: botulin; Beac: betulinic acid; Lu: lupeol; Urac; ursolic acid; $\alpha$-a: $\alpha$-amyrin; $\beta$-a: $\beta$-amyrin; $24 \mathrm{mc:} 24$ methylenecycloartanol 


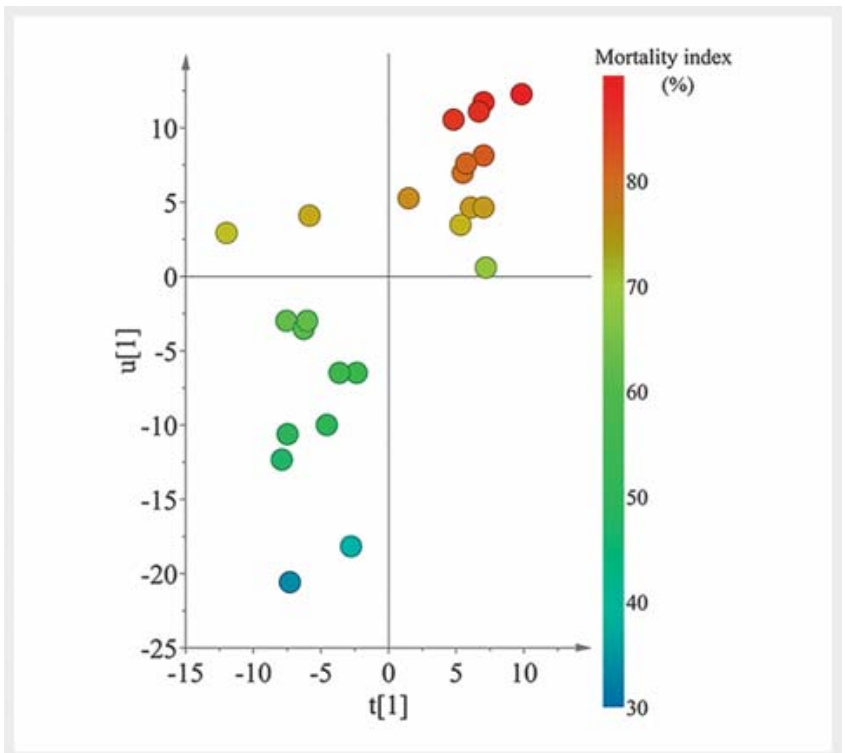

- Fig. 7 Partial least square analysis of antiherbivory activity against Frankliniella occidentalis and the ${ }^{1}$ HNMR data set of the $\mathrm{MeOH}$ extracts of latex and leaves.

by lowering the mobility of fatty acid chains in the cell membrane [39]. In this way, varying the type, ratio, and quantity of diverse membrane sterols can even influence plant microorganisms' interactions $[40,41]$.

The latex aqueous fractions showed very simple patterns compared with the lipophilic fractions, exhibiting just a few characteristic signals of organic acids in high concentrations in several samples. The role of the organic acids in latexes has been relatively less studied than that of triterpenoids or sterols. However, the role of organic acids in plant-herbivore interactions has been linked to herbivore preference due to the acid-bitter taste they confer to containing tissues [42]. Also, according to a recent report, malic acid can favor beneficial bacteria as it is involved in their biofilm formation for host-plant protection [43]. In the case of A. scholaris, 1 new analog of succinic acid was found to be almost a unique component in the water fraction. However, when compound 4 was tested against thrips, the compound did not show any significant activity, even when combined with terpenoids. This could suggest indirect complementation of this type of chemical component in the latex-related defense.

There might be another role of these highly concentrated organic acids. Latex coagulation has been reported to improve under acidic conditions [44]. Gidrol and colleagues [44] found that the binding efficacy of coagulation proteins was $\mathrm{pH}$-dependent and at its highest at low pH. Moreover, Oliveira-Reis and coworkers [45] studied the effect of the rubber particle size and $\mathrm{pH}$ on the kinetics of natural rubber gelation, finding that rubber fractions at concentrations above $10^{-2}$ particles per milliliter with a $\mathrm{pH}$ close to 4 resulted in the full gelation of the rubber suspensions. Therefore, a highly concentrated organic acid might serve as a buffer or regulator medium modulating the latex coagulation speed. However, the specificity of the organic acid is still doubtful.

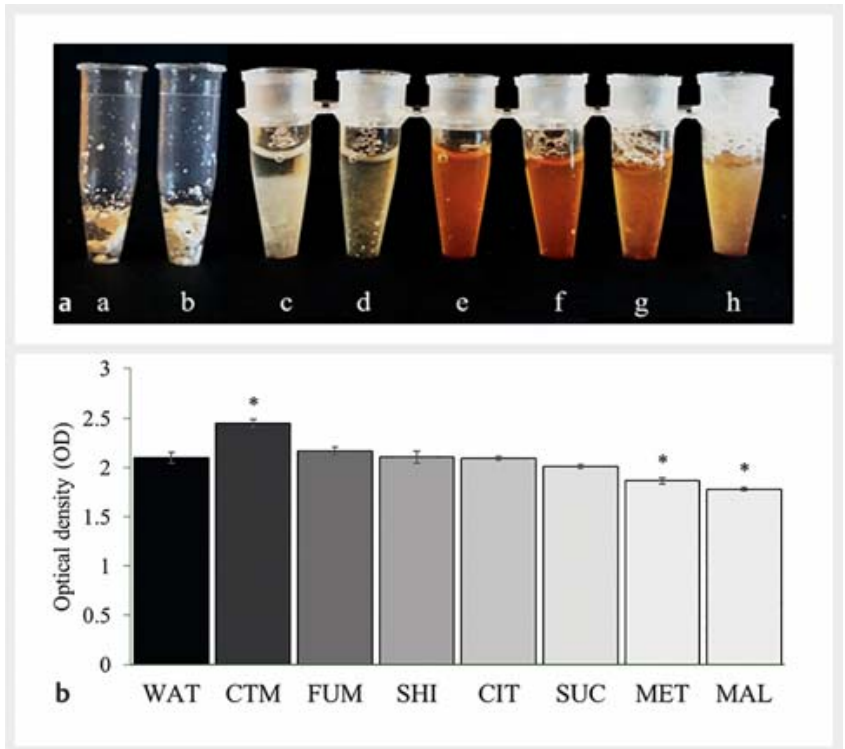

- Fig. 8 Effects of 2-methoxysuccinic acid (2MET) and other organic acids on latex coagulation. a Effect of mixtures of 2MET with latex suspensions of Alstonia scholaris, Adenium obesum, Jatropha curcas, and Jatropha multifida. a: A. scholaris; b: A. scholaris latex control; c: A. obesum; d: A. obseum latex control; e: J. curcas; f: J. curcas latex control; g: J. multifida; h: J. multifida latex control. b Effects of organic acids on the latex of J. multifida; WAT: water control, CITRA: citramalic acid, CITRIC: citric acid, FUM: fumaric acid, SHI: shikimic acid, SUC: succinic acid, 2MET: 2-methoxysuccinic acid, MAL: malic acid. The data represent average values $(n=4) \pm$ standard error. Bars with an * indicate significant differences as compared with the water control in a Dunnett test $(p<0.05)$.

In summary, the effects of acids could enhance the mechanical defense of latexes by speeding up the coagulation process, and this could trap more insect herbivores, as well as provide the optimum $\mathrm{pH}$ for gelation $[45,46]$.

To test the specificity of organic acids, freeze-dried powders of the latexes of $A$. scholaris, $A$. obesum, J. multifida, and J. curcas were resuspended in pure water and supplemented with compound 4. As expected in the case of the latex of $A$. scholaris (source of the tested compound), the rate of coagulation increased ( $\vee$ Fig. 8 a). However, adding the same compound to the other latexes did not always have the same effect. In A. obesum, the compound also increased the coagulation speed, whereas there was no effect in J. multifida. Moreover, in the case of J. curcas, the organic acid showed the opposite effect, that is, the latex suspension was stabilized and the coagulation process was delayed ( $\vee$ Fig. $\mathbf{8}$ a). These results demonstrated that compound 4 is an enhancer of the latex coagulation in A. scholaris and potentially a species-specific coagulation enhancer.

The specificity of organic acids in the coagulation process was further studied by spectrophotometry using J. curcas latex. Apart from compound 4 , the common organic acids succinic acid, malic acid, citric acid, citramalic acid, fumaric acid, and shikimic acid were tested at the same concentration as detected in latex $(\mathrm{pH} 2.5)$ and spectrophotometrically compared. They showed dif- 
ferent effects: as previously observed, compound 4 showed a lower $\mathrm{OD}$ value when compared to that of the negative control (water), indicating a lower coagulation rate; a similar effect was observed with malic acid, but citramalic acid increased the coagulation rate ( $\bullet$ Fig. $\mathbf{8} \mathbf{b}$ ). The rest of the compounds did not affect the coagulation process. The results strongly indicate that the coagulation process is not only $\mathrm{pH}$-dependent but also relies on chemically specific interactions. Moreover, this could explain the presence of organic acids in the water fractions. It could also indicate that the variation of this type of metabolites among species is the result of species-specific interactions with other nonpolar metabolites correlated to the coagulation process [6].

Based on these results, it can be stated that latexes possess distinctive metabolomes from their bearing tissues, which reflect the biological specialization of their specific specialized metabolites. The singular chemical profile of latexes consisted mainly of a semi-conserved chemical constitution. This similarity, however, occurs at a compound class level rather than at a specific metabolite level, confirming a specialized chemical selection for the dedicated roles of these exudates. Triterpenoids were deduced to be correlated to the antiherbivore activity against thrips by ${ }^{1} \mathrm{HNMR}$-based metabolic analysis in which characteristic ${ }^{1} \mathrm{H}$ resonances of triterpenoids were detected. However, this type of terpenoid seems to be involved in a complementary system together with other chemical components of latexes. The specific metabolites of latexes are not limited to lipophilic components but also consist of water-soluble organic acids. These acids did not show any activity against thrips but were correlated to the regulation of the coagulation process in a chemo-specific way. In other words, the effect of these metabolites could improve latex-related defense by speeding up the coagulation process, thus improving the mechanical defense of latexes. Latexes are thus an example offered by nature of a chemo-systematic substance efficiently optimized for plant defense. That is, even if the character of the chemical constitution of latex is primary constitutive, thus preselected and with a finite number of metabolites, their interactions can increase the number of defensive tactics given by this sap to thrive against natural enemies.

\section{Materials and Methods}

\section{Chemicals and materials}

All solvents and reagents used in extraction and fractionations were of analytical grade. Hexane for GC-MS analysis was GC grade. Reference compounds of betulin, $\beta$-sitosterol, stigmasterol, $a$ amyrin, $\beta$-amyrin, and lupenone were purchased from SigmaAldrich, and 24-methylenecycloartanol was previously isolated from the latex of Euphorbia palustris [18].

\section{Plant material and sampling}

Diverse latexes and their bearing leaves were collected from 4 major latex-producing plant families: Apocynaceae (Alstonia scholaris, Adenium obesum, Allamanda ssp., Plumeria rubra, Dischidia bengalensis, and Acokanthera obloguifolia), Euphorbiaceae (Jatropha multifida, Jatropha curcas, Euphorbia tirucalli, and Euphorbia myrsinites), Moraceae (Ficus natalensis), and Clusiaseae (Clusia ro- sea). Among these, the latex of J. curcas, J. multifida, and A. obesum was non-rubbery while the other species produced rubbery latexes. Samples were collected in February 2017 at the Botanical garden of Leiden University (Hortus Botanicus, Leiden, The Netherlands). The plants used in the study were identified by Rogier van Vugt: Acokanthera obloguifolia (NPLRS-LB-AO20160318-1), Adenium obesum (NPLRS-LB-AO2015910-0-1), Allamanda ssp. (NPLRS-LB-AX-20160710-X), Clusia rosea (NPLRSLB-CR-20180230-1), Dischidia bengalensis (NPLR-LB-DB20160710-0), Euphorbia myrsinites (NPLRS-LB-EM-20140513-0), Euphorbia tirucalli (NPLRS-LB-ET-20140513-1), Ficus triangularis (nataliensis) (NPLRS-LB-FT-20140513-2), Jatropha curcas (NPLRSLB-JC-20140513-3), Jatropha multifida (NPLRS-LB-JM-201405134), and Plumeria rubra (NPLRS-LB-PR-20140513-5). Latex samples were obtained by cutting the tree trunk or plant stems with a sterile razor blade and collecting the flowing latex in 2-mL microtubes within 3 minutes. The samples were flash-frozen in liquid nitrogen and stored at $-80^{\circ} \mathrm{C}$ until they were freeze-dried. The leaf samples were manually collected from the plant. The leaves were left to drain as much latex as possible and placed into plastic airtight bags and frozen in liquid nitrogen. The frozen leaf samples were ground to a fine powder and placed in $50-\mathrm{mL}$ conical tubes. These samples were also stored at $-80^{\circ} \mathrm{C}$ until they were freezedried.

\section{Sample extraction and fractionation}

Methanol extracts were prepared by ultra-sonicating $100 \mathrm{mg}$ of dry latex or leaf material with $20 \mathrm{~mL}$ of methanol for $20 \mathrm{~min}$. The methanol extracts were filtered and concentrated with a rotary evaporator (Büchi). The concentrated extracts were transferred to $1.5 \mathrm{~mL}$ glass vials and taken to total dryness with a vacuum concentrator (Labconco). To obtain 3 fractions from latexes, freezedried latex samples were re-suspended in $20 \mathrm{~mL}$ of deionized water, ultra-sonicated for $20 \mathrm{~min}$, and then sequentially extracted with $3 \times 20 \mathrm{~mL}$ of dichloromethane and ethyl acetate, yielding a dichloromethane and ethyl acetate fractions, respectively. The remaining water after liquid-liquid extraction was taken as the leftover water fraction. When latex particles were not completely dissolved in water, the tube was washed with the first extraction solvent. In the case of layers of stable emulsions, the emulsion was left in the aqueous phase. The organic fractions were dried with anhydrous sodium sulfate, filtered, and concentrated with a rotary evaporator. The fractions were then taken to total dryness in $1.5 \mathrm{~mL}$ glass vials with a vacuum concentrator. The dried methanol leaf extracts were re-suspended into $20 \mathrm{~mL}$ of deionized water and fractionated as indicated for latexes.

\section{NMR}

For ${ }^{1} \mathrm{HNMR}$ profiling, the dried methanol extracts and dichloromethane and ethyl acetate fractions from latexes and leaves were re-dissolved in $500 \mu \mathrm{L}$ of $\mathrm{CH}_{3} \mathrm{OH}-d_{4}$ containing $0.418 \mathrm{mM}$ hexamethyldisiloxane (HMDSO). Water fractions were dissolved in a mixture of $\mathrm{CH}_{3} \mathrm{OH}-d_{4}-\mathrm{KH}_{2} \mathrm{PO}_{4}$ buffer in $\mathrm{D}_{2} \mathrm{O}(1: 1, \mathrm{v} / \mathrm{v}, \mathrm{pH} 6.0)$ containing $0.005 \%(\mathrm{w} / \mathrm{w})$ of trimethylsilylpropionic acid sodium salt- $d_{4}$ (TMSP). The extracts were ultra-sonicated for $20 \mathrm{~min}$, centrifuged at $13000 \mathrm{rpm}$ for $10 \mathrm{~min}$, and transferred to $3 \mathrm{~mm}-\mathrm{NMR}$ tubes. The ${ }^{1} \mathrm{HNMR}, 2 \mathrm{D}-\mathrm{J}$-resolved, ${ }^{1} \mathrm{H}-{ }^{1} \mathrm{H}$ correlated spectroscopy, 
${ }^{1} \mathrm{H}-{ }^{1} \mathrm{H}$ homonuclear COSY, and $\mathrm{HMBC}$ were performed using a $600-\mathrm{MHz}$ Bruker spectrometer (Bruker), operating at a proton NMR frequency of $600.13 \mathrm{MHz}$. For internal locking, $\mathrm{CH}_{3} \mathrm{OH}-d_{4}$ was used. All ${ }^{1} \mathrm{HNMR}$ analyses consisted of 128 scans, requiring an acquisition time of $10 \mathrm{~min}$ and $26 \mathrm{sec}$. Acquisition parameters were: $0.16 \mathrm{~Hz} /$ point, pulse width $(P W)=30^{\circ}(11.3 \mu \mathrm{s})$, and the relaxation time was $1.5 \mathrm{sec}$. A pre-saturation sequence was used to suppress the residual $\mathrm{H}_{2} \mathrm{O}$ signal using low power selective irradiation at $\mathrm{H}_{2} \mathrm{O}$ frequency during the recycle delay. The FIDs were Fourier transformed with exponential line broadening of $0.3 \mathrm{~Hz}$. The resulting spectra were manually phased and baseline corrected, and calibrated to TMSP and HMDSO at 0.00 and $0.06 \mathrm{ppm}$ respectively for latexes and leaves samples using TOPSPIN V. 3.0 (Bruker BioSpin). The same previously reported parameters were used for J-resolved, COSY, and HMBC [47].

For total organic acid quantitation, the ratio between representatives resonances in water fractions $\mathrm{H}-3$ ( $\delta 4.43$, brt, $J=4.2 \mathrm{~Hz}$ ), H-3 ( $\delta 4.55$, brt, $J=4.2 \mathrm{~Hz}), \mathrm{H}-3(\delta 5.54$, brt, $J=4.2 \mathrm{~Hz})$ signals in $E$. myrsinites, $\mathrm{H}-2(\delta 3.99$, dd, $J=10.5,3.0 \mathrm{~Hz})$ in A. scholaris, and $\mathrm{H}-2(\delta 7.82, \mathrm{t}, J=1.8 \mathrm{~Hz})$ in P. rubra, and the internal standard (TMSP) signal ( $\delta 0.00)$ was used in the formula: TISTr $\times$ HIST $\times[$ IST $] /$ HTS, where TISTr $=$ ratio between target signal and internal standard signal, HIST = number of protons in the internal standard signal, [IST] = concentration of the internal standard in the sample, and HTS = number of protons in the target signal. For total triterpene content, lanosterol/euphol was selected as a representative major triterpene component. Thus, the ratio between the $\mathrm{H}-26(\delta 1.61, \mathrm{~d})$ of the lanostan skeleton and the internal standard (HMDSO) signal $(\delta 0.06)$ was used in the same formula as for organic acids' quantitation.

\section{Gas chromatography coupled to mass spectrometry (GC-MS)}

Latex dichloromethane fractions were analyzed by GC-MS to identify fatty acids and terpenoids detected by ${ }^{1}$ HNMR. For sample derivatization, $100 \mu \mathrm{L}$ of dichloromethane fractions solution $(2 \mathrm{mg} /$ $\mathrm{mL}$ ) were mixed with $200 \mu \mathrm{L}$ of pyridine and $100 \mu \mathrm{L}$ of BSTFA with $1 \%$ of TMCS (SUPELCO). The solutions were heated at $80^{\circ} \mathrm{C}$ for $50 \mathrm{~min}$, cooled to room temperature, and analyzed on an Agilent technologies 7890A gas chromatograph equipped with an autosampler (7693) and coupled to an Agilent technologies 5975C mass detector (Agilent). Samples $(1 \mu \mathrm{L})$ were injected in split mode (10:1) into a DB5/50 $\mathrm{m} \times 0.20 \mathrm{~mm}$ and $0.33 \mu \mathrm{m}$ thickness column (J\&W Science). Helium ( $99.9 \%$ purity) was used as a carrier gas at a flow rate of $1 \mathrm{~mL} / \mathrm{min}$. For the analysis of $A$. obesum latex and leaf dichloromethane fractions, the initial temperature was $200^{\circ} \mathrm{C}$ increasing at $4{ }^{\circ} \mathrm{C} / \mathrm{min}$ to $280^{\circ} \mathrm{C}$ and then at $0.5^{\circ} \mathrm{C}$ min to $290^{\circ} \mathrm{C}$ followed by a 3-minute hold. For E. myrsinites, E. tirucalli, A. oblonguifolia, P. rubra, D. bengalensis, A. scholaris, and C. rosea latex and leaf dichloromethane fractions and the $F$. natalensis dichloromethane latex fraction, the initial temperature was $200^{\circ}$ $\mathrm{C}$, increasing at $10^{\circ} \mathrm{C} / \mathrm{min}$ to $280^{\circ} \mathrm{C}$ and then $0.5^{\circ} \mathrm{C} / \mathrm{min}$ to $290^{\circ} \mathrm{C}$ followed by a 3 -min hold. Finally, for $\mathrm{F}$. natalensis leaves, Allamanda sp., J. curcas, and J. multifida latex and leaf dichloromethane fractions, the initial temperature was $150^{\circ} \mathrm{C}$ increasing at $5{ }^{\circ} \mathrm{C}$ min to $280^{\circ} \mathrm{C}$, then $0.5^{\circ} \mathrm{C} / \mathrm{min}$ to $290^{\circ} \mathrm{C}$ and held for $3 \mathrm{~min}$. The injector temperature and interface for the MS were set at $280^{\circ} \mathrm{C}$.
Samples were detected in SCAN mode, ion source temperature was $230^{\circ} \mathrm{C}$, quadrupole was $150^{\circ} \mathrm{C}$, and ionization energy was $70 \mathrm{eV}$. Peak identification was done by comparison of the ion spectra of sample peaks with ion spectra in the NIST library (V. 2008) or of their retention time with standard compounds.

\section{Anti-herbivory activity}

Thrips (Frankliniella occidentalis) were reared in a climate chamber on chrysanthemum plants, from which they were able to feed. The insects were obtained from an established colony of the Plant Ecology Laboratory of the Institute of Biology Leiden, Leiden University [25]. The thrips were contained inside plastic cages in standard thrips rearing conditions ( $\left.\mathrm{L}: \mathrm{D}, 12: 12,25^{\circ} \mathrm{C}\right)$. For the bioactivity assays, adult thrips were taken from these cages and placed inside jars containing string beans as food. To obtain thrips larvae, the jars were kept in the same breeding conditions for 7 days. Second instar larvae were used for the bioassays. The larvae were placed into cap strips (1 larva/cap), and subsequently, the caps were sealed with parafilm. For the assay, 96 well-plates were filled with $55 \mu \mathrm{L}$ of control and treatment diet solutions, and the cap strip bands containing the larvae were placed on top of the 96 well plates upside down, allowing the thrips to feed through the parafilm. After 5 days, the larvae survival index was recorded using a stereomicroscope. Three independent replicates were done for all the experiments $(n=32)$.

\section{Controls and treatments}

For the first experimental stage, treatment solutions were prepared with latex and leaf methanol extracts dissolved in $40 \mathrm{mM}$ phosphate buffer $(\mathrm{pH} 7)$ containing $10 \%$ fructose. All solutions had a final concentration of $150 \mu \mathrm{g} / \mathrm{mL}$ and $3 \%$ methanol in the well. For the second experimental stage, the treatment solutions were prepared with dichloromethane, ethyl acetate, and water fractions of 6 latexes from Euphorbiacae (J. multifida, J. curcas, and E. myrsinites), and Apocynacae (A. scholariş A. obesum, and $P$. rubra) families. The dried fractions were re-dissolved in DMSO and diluted in $40 \mathrm{mM}$ phosphate buffer $(\mathrm{pH} 7)$ with $10 \%$ fructose. Again, the final concentration of the solutions was $150 \mu \mathrm{g} / \mathrm{mL}$ and $1 \%$ DMSO in the well. For the third experimental stage, the treatment solutions were prepared with betulin, betulinic acid, $\alpha$-amyrin, $\beta$-amyrin, ursolic acid, lupeol, and 24-methylenecycloartanol at a final concentration of $37.5 \mu \mathrm{g} / \mathrm{mL}$ dissolved in the same buffer used for the fractions treatments.

Negative controls for all bioactivity assays consisted of solutions of $40 \mathrm{mM}$ phosphate buffer $(\mathrm{pH} 7)$ containing $10 \%$ fructose, and $3 \%$ methanol for methanol extracts and $1 \%$ of DMSO for fractions and pure compounds. A $150 \mu \mathrm{g} / \mathrm{mL}$ solution of abamectin in the previous mixtures was used as a positive control. Empty wells were used as another positive control to prove that thrips larvae could not survive without feeding.

\section{Coagulation experiments}

A $6.7 \mathrm{mM}$ aqueous solution of 2-methoxy succinic acid was prepared to test its effect on the coagulation process of the latexes of $A$. scholaris and other species. In the case of $A$. scholaris, $5 \mathrm{mg}$ of freeze-dried latex was re-suspended in $100 \mu \mathrm{L}$ of the 2-methoxy succinic acid solution in $500 \mu \mathrm{L}$ plastic micro-tubes. For $A$. obesum, 
J. mutifida, and J. curcas, $3 \mathrm{mg}$ of freeze-dried latex was re-suspended in $150 \mu \mathrm{L}$ of the acid solution. The negative controls consisted of the same latexes re-suspended in milliQ water. The effects of the treatment were evaluated by visual inspection after 20 min exposure to open-air conditions. The amount of solution was adjusted to obtain a similar consistency to that of the natural flowing latexes.

\section{Spectrophotometric assays}

Three milligrams of freeze-dried latex of J. curcas were individually placed in a 96 flat bottom well plate, and $150 \mu \mathrm{L}$ of aqueous solutions of 2-methoxy succinic acid, succinic acid, malic acid, citric acid, citramalic acid, fumaric acid, and shikimic acid (6.7 mM) were added to each well. The latexes were dissolved, and to avoid the interference of bubbles and foam in the optical density reading, $100 \mu \mathrm{L}$ of these solutions were subsequently gently transferred to the next row of wells. The coagulation control consisted of latex redissolved in deionized water. The blank solutions were $6.7 \mathrm{mM}$ aqueous solutions of each organic acid mixed with water for the coagulation control. The spectrophotometric measurements were carried out in a $680 \mathrm{XR}$ multi-well plate reader (BIO-RAD) at $600 \mathrm{~nm}$ after $20 \mathrm{~min}$ at room temperature $\left(22^{\circ} \mathrm{C}\right)$ and exposed to air (without a lid). The results were expressed in OD values \pm standard deviation $(n=4)$.

\section{Data processing and statistical analysis}

Spectral data was bucketed using the AMIX program (V. 3.9.12, Bruker BioSpin); bucket size was 0.04 ppm and the areas were normalized to total intensity. Intervals corresponding to methanol and water signals were deleted from the bucket data. MVDA was performed using SIMCA P (V. 15.1, Umetrics). PCA and orthogonal projections to latent structures discriminant analysis (OPLS-DA) were performed for NMR data. Data for PCA and OPLS-DA data was scaled using Pareto scaling.

To calculate mortality indexes, the mortality ratio of the methanol and DMSO extracts for both latex and leaves were corrected for the survival of its corresponding negative control. To evaluate differences in bioactivity between latex and leaves across all species, a generalized linear mixed model for binomial data was constructed. In this model, the survival rate of the corresponding negative control was again used to correct for the survival of the negative control for each species. Therefore, an offset was constructed with the negative control of each species. The data for each species was also compared to determine whether there was a difference in bioactivity between latex and leaf extracts from different species. The effect of species was set as a random effect in the offset of the model. The same model was used to compare the treatments of fractions. To compare the antiherbivore effects of individual compounds with the latex mean value, a 2-tailed t-test for samples with the same variance was performed for each comparison. For coagulation experiments, the OD average of each treatment $(n=4)$ was compared with that of the coagulation control by a Dunnett test $(\alpha=0.05)$. All tests were performed using R software (V 1.1.456).

\section{Supporting Information}

Information about compound spectra (2D NMR spectrum) is available as Supporting Information.

\section{Contributors' Statement}

Conception and design of the work: L.F. Salomé-Abarca, Y.H. Choi, Klinkhamer P.G.L.; data collection: L.F. Salomé-Abarca, T. van der Toorn, R. van Vugt; analysis and interpretation of the data: L. F. Salomé-Abarca, T. van der Toorn, Y. H. Choi, R. van Vugt, Klinkhamer P. G. L.; statistical analysis: L. F. Salomé-Abarca, T. van der Toorn, Y.H. Choi, R. van Vugt, Klinkhamer P. G. L.; drafting the manuscript: L. F. Salomé-Abarca, T. van der Toorn; critical revision of the manuscript: Y. H. Choi, R. van Vugt, Klinkhamer P. G. L.

\section{Acknowledgements}

The first author thanks the Mexican Scientific Council (CONACyT) for supporting his Ph.D. scholarship (No. 410812).

\section{Conflict of Interest}

The authors declare that they have no conflict of interest.

\section{References}

[1] Konno K. Plant latex and other exudates as plant defense systems: roles of various defense chemicals and proteins contained therein. Phytochemistry 2011; 72: 1510-1530

[2] Agrawal AA, Konno K. Latex: A model for understanding mechanisms, ecology, and evolution of plant defense against herbivory. Annu Rev Ecol Evol Syst 2009; 40: 311-331

[3] Agrawal AA, Lajeunesse M], Fishbein M. Evolution of latex and its constituent defensive chemistry in milkweeds (Asclepias): a phylogenetic test of plant defense escalation. Entomol Exp Appl 2008; 128: 126-138

[4] Huber M, Triebwasser-Freese D, Reichelt M, Heiling S, Paetz C, Chandran JN, Bartram S, Schneider B, Gershenzon J, Erb M. Identification, quantification, spatiotemporal distribution and genetic variation of major latex secondary metabolites in the common dandelion (Taraxacum officinale agg.). Phytochemistry 2015; 115: 89-98

[5] Ramos MV, Grangeiro TB, Freire EA, Sales MP, Souza DP, Araújo ES, Freitas CDT. The defensive role of latex in plants: detrimental effects on insects. Arthropod Plant Interact 2010; 4: 57-67

[6] Bauer G, Gorb SN, Klein MC, Nellesen A, von Tapavicza M, Speck T. Comparative study on plant latex particles and latex coagulation in Ficus benjamina, Campanula glomerata and 3 Euphorbia species. PLoS One 2014; 9: e113336

[7] Pandey BP. Plant Anatomy. New Delhi: S. Chand and Company; 2001

[8] Taira T, Ohdomar A, Nakama N, Shimoji M, Ishihara M. Characterization and antifungal activity of Gazyumaru (Ficus microcarpa) latex chitinases: both the chitin-binding and the antifungal activities of class I chitinase are reinforced with increasing ionic strength. Biosci. Biotechnol Biochem 2005; 69: 811-818

[9] Seiber JN, Nelson C], Lee SM. Cardenolides in the latex and leaves of seven Asclepias species and Calotropis procera. Phytochemistry 1982; 21: 2343-2348

[10] Groeneveld HV, van den Berg B, Elings JC, Seykens D. Cardenolide biosynthesis from malonate in Asclepias curassavica. Phytochemistry 1990; 29: 3479-3486

[11] Groeneveld HV, Binnekamp A, Seykens D. Cardenolide biosynthesis from acetate in Asclepias curassavica. Phytochemistry 1991; 30: 2577-2585 
[12] Sessa R, Benett MH, Lewin M], Mansfirls JW, Beale MH. Metabolite profiling of sesquiterpene lactones from Lactuca species. J Biol Chem 2000; 275: 26877-26884

[13] Konno K, Hirayama C, Nakamura M, Tateishi K, Tamura Y, Hattori M, Kohno K. Papain protects papaya trees from herbivorous insects: role of cysteine protease in latex. Plant J 2004; 37: 370-378

[14] Konno K, Ono H, Nakamura M, Tateishi K, Hirayama C, Tamura Y, Hattori M, Koyama A, Kohno K. Mulberry latex rich in antidiabetic sugar-mimic alkaloids forces dieting on caterpillars. Proc Natl Acad Sci U S A 2006; 103: 1337-1341

[15] Chezem WR, Clay NK. Regulation of plant secondary metabolism and associated specialized cell development by MYBs and bHLHs. Phytochemistry 2016; 131: 26-43

[16] Freitas CDT, Silva RO, Ramosa MV, Porfírio CTMN, Farias DF, Sousa JS, Oliveira JPB, Souza PFN, Dias LP, Grangeiro TB. Identification, characterization, and antifungal activity of cysteine peptidases from Calotropis procera latex. Phytochemistry 2020; 169: 112163

[17] Ghanbari A, Le Gresley A, Naughton D, Kuhnert N, Sirbu D, Ashrafi GH. Biological activities of Ficus carica latex for potential therapeutics in human papillomavirus (HPV) related cervical cancers. Sci Rep 2019; 9: 1013

[18] Krstić G, Anđelković B, Choi YH, Vajs V, Stević T, Tešević V, Gođevac D. Metabolic changes in Euphorbia palusrtis latex after fungal infection. Phytochemistry 2016; 131: 17-25

[19] Nicholson JK, Connelly J, Lindon JC, Holmes E. Metabonomics: a platform for studying drug toxicity and gene function. Nat Rev Drug Disc 2002; 1 : 153-161

[20] Ellis DI, Brewster VL, Dunn WB, Allwood JW, Golovanov AP, Goodacre R. Fingerprinting food: current technologies for the detection of food adulteration and contamination. Chem Soc Rev 2012; 41: 5706-5727

[21] Kim HK, Choi YH, Verporrte R. NMR-based metabolomic analysis of plants. Nat Protoc 2010; 5: 536-549

[22] Gromski PS, Muhamadali H, Ellis DI, Xu Y, Correa E, Turner ML, Goodacre R. A tutorial review: metabolomics and partial least squares-discriminant analysis - a marriage of convenience or a shotgun wedding. Anal Chim Acta 2015; 879: 10-23

[23] Markley JL, Brüschweiler R, Edison AS, Eghbalnia HR, Powers R, Raftery D, Wishart DS. The future of NMR-based metabolomics. Curr Opin Biotechnol 2017; 43: 34-40

[24] Kirk WD], Terry LI. The spread of the western flower thrips Frankliniella occidentalis (Pergande). Agric For Entomol 2003; 5: 301-310

[25] Liu X, Klinkhamer PGL, Vrieling K. The effect of structurally related metabolites on insect herbivores: a case study on pyrrolizidine alkaloids and western flower thrips. Phytochemistry 2017; 138: 93-103

[26] Maffei ME, Mithöfer A, Boland W. Insects feeding on plants: rapid signals and responses preceding the induction of phytochemical release. Phytochemistry 2007; 68: 2946-2959

[27] Bruinsma M, Posthumus MA, Mumm R, Mueller M], van Loon JJA, Dicke M. Jasmonic acid-induced volatiles of Brassica oleracea attract parasitoids: effects of time and dose, and comparison with induction by herbivores. J Exp Bot 2009; 60: 2575-2587
[28] Hare JD. Ecological role of volatiles produced by plants in response to damage by herbivorous insects. Annu Rev Entomol 2011; 56: 161-180

[29] War AR, Paulraj MG, Ahmad T, Buhroo AA, Hussain B, Ignacimuthu S, Sharma HC. Mechanisms of plant defense against insect herbivores. Plant Signal Behav 2012; 7: 1306-1320

[30] Snook ME. Characterization and quantification of hexadecyl, octadecyl and eicosyl esters of p-coumaric acid in the vine and root latex of sweet potato (Ipomoea batatas (L.) Lam.). J Agric Food Chem 1994; 42: 25892595

[31] Schmeller T, Latz-Brüning B, Wink M. Biochemical activities of berberine, palmatine and sanguinarine mediating chemical defense against microorganisms and herbivores. Phytochemistry 1997; 44: 257-266

[32] Appel HM. Phenolics in ecological interactions: the importance of oxidation. J Chem Ecol 1993; 19: 1521-1552

[33] Mason CM, Bowsher AW, Crowell BL, Celoy RM, Tsai C], Donovan LA. Macroevolution of leaf defenses and secondary metabolites across the genus Helianthus. New Phytol 2016; 209: 1720-1733

[34] Agrawal AA, Fishbein M. Plant defense syndromes. Ecology 2006; 87: S132-S149

[35] Agrawal AA. Macroevolution of plant defense strategies. Trends Ecol Evol 2007; 22: 103-109

[36] González-Coloma A, López-Balboa C, Santana O, Reina M, Fraga BM. Triterpene-based plant defenses. Phytochem Rev 2011; 10: 245-260

[37] Shankaranarayana KH, Ayyar KS, Rao GSK. Insect growth inhibitor from the bark of Santalum album. Phytochemistry 1980; 19: 1239-1240

[38] Michelozzi M. Defensive roles of terpenoid mixtures in conifers. Acta Bot Gallica 1999: 146: 73-84

[39] Lewis WH, Elvin-Lewis MPF. Medical Botany: Plants Affecting Man's Health. New York: Wiley; 1977.

[40] Griebel T, Zeier ]. A role for $\beta$-sitosterol to stigmasterol conversion in plant-pathogen interactions. Plant J 2010; 63: 254-268

[41] Sharfman M, Bar M, Schuster S, Leibman M, Avni A. Sterol-dependent induction of plant defense responses by a microbe-associated molecular pattern from Trichoderma viride. Plant Physiol 2014; 164: 819-827

[42] Cipollini ML, Stiles EW. Antifungal activity of ripe ericaceous fruits: phenolic-acid interactions and palatability for dispersers. Biochem Syst Ecol 1992; 20: 501-514

[43] Rudrappa T, Czymmek KJ, Paré PW, Bais HP. Root-secreted malic acid recruits beneficial soil bacteria1. Plant Physiol 2008; 148: 1547-1556

[44] Gidrol X, Chrestin H, Tan HL, Kush A. Hevein, a lectin-like protein from Hevea brasiliensis (Rubber Tree) is involved in the coagulation of latex. J Biol Chem 1994; 269: 9278-9283

[45] De Oliveira-Reis G, Menut P, Bonfils F, Vaysse L, Hemar Y, Sanche C. Acidinduced aggregation and gelation of natural rubber latex particles. Colloid Surf A Physicochem Eng Asp 2015; 482: 9-17

[46] Dussourd DE. Entrapment of aphids and whiteflies in lettuce latex. Ann Entomol Soc Am 1995; 88: 163-172

[47] Kim HY, Khan S, Wilson EG, Prat-Kricun SD, Meissner A, Goraler S, Deelder AM, Choi YH, Verpoorte R. Metabolic classification of South American Ilex species by NMR-based metabolomics. Phytochemistry 2010; 71: $773-784$ 